\title{
DOI:10.33766/2524-0323.95.118-129
}

УДК 343.222.1:343.615.4(477)

Шамсутдінов О. В., кандидат юридичних наук, профресор кафредри кримінального права, кримінального прочесу та криміналістики Національної академії Служби безпеки України (м. Киї, Україна)

e-mail: sun091141@gmail.com

ORCID iD: http://orcid.org/0000-0002-9325-9227

\section{ОСОБЛИВОСТІ ЗМІСТУ ВИНИ В КРИМІНАЛЬНИХ ПРАВОПОРУШЕННЯХ ЗІ СКЛАДНОЮ ОБ'ЄКТИВНОЮ СТОРОНОЮ (СТАТTI 272-275, 326 КК УКРАЇНИ)}

У статті досліджено питання про зміст вини як обов'язкової ознаки суб'єктивної сторони складу кримінальних правопорушень зі складною об'єктивною стороною, яка передбачає діяння у формі порушення спеціальних правил безпеки та декілька альтернативних наслідків. Детально розглянуто особливості інтелектуальних і вольових моментів умисної та необережної форм вини в кримінальних правопорушеннях, передбачених статтями 272-275, 326 КК України.

Зроблено висновок про те, що при умисному порушенні спеціальних правил безпеки психічне ставлення особи до суспільно небезпечних наслідків першого порядку (створення реальної загрози) характеризується непрямим умислом або злочинною самовпевненістю, а до наслідків другого і третього порядку (заподіяння реальної шкоди) можливим є лише необережне ставлення винуватої особи. Аргументовано твердження, що зі злочинною недбалістю при вчиненні досліджуваних правопорушень суб' єкт ставиться як до діяння, так і до його наслідків, тобто складна форма вини виключаеться.

Ключові слова: вина, складна форма вини, умисел, необережність, порушення спеціальних правил безпеки, делікт створення небезпеки.

Постановка проблеми. Кваліфікація злочину є основним етапом, стрижневою ланкою застосування кримінально-правової норми, оскільки правильна юридична оцінка вчиненого особою діяння є необхідною умовою досягнення законності при відправленні правосуддя. У цьому контексті питання здійснення належної кримінально-правової оцінки дійсних внутрішніх проявів особи при вчиненні нею суспільно небезпечного діяння, а також суб'єктивного ставлення до наслідків такого діяння має істотне, а іноді й визначальне значення для правильної кваліфікації вчиненого, відмежування його від суміжних кримінальних правопорушень та призначення справедливого покарання.

У випадках, коли форма вини прямо не визначена в диспозиції конкретної кримінально-правової норми, виникає ситуація, коли науковці-правники та суб'єкти правозастосовної діяльності по-різному тлумачать цю суб'єктивну ознаку, що може призвести до порушення принципу справедливості, законності та винуватості. Саме такий стан справ є характерним для диспозицій низки кримінальноправових норм, які встановлюють відповідальність за порушення спеціальних правил безпеки (ст.ст. 272-275, 326 КК України). Указані кримінальні правопорушення () Шамсутдінов О. В., 2021 
належать до складних злочинів, які характеризуються наявністю двох і більше безпосередніх об'єктів, настанням різних альтернативних наслідків, залежно від чого ці кримінальні правопорушення можуть бути деліктами створення небезпеки або ж класичними злочинами з матеріальним складом.

У теорії кримінального права України та відповідній правозастосовній практищі визнано, що для таких типів злочинів також притаманна складна форма вини, коли психічне ставлення особи до вчинюваного нею діяння виражається в умислі, а до наслідків - у необережності. Чітке з'ясування інтелектуальних і вольових моментів цих форм вини має велике теоретичне та практичне значення.

Аналіз останніх досліджень і публікацій. Дослідженням правової оцінки випадків поєднання різних форм вини присвячено праці багатьох вітчизняних та зарубіжних вчених, зокрема: М. І. Бажанова, Ю. В. Бауліна, В. І. Борисова, Р. В. Вереши, Н. О. Гуторової, В. П. Ємельянова, О. М. Костенка, А. О. Пінаєва, О. Я. Свєтлова, С. А. Тарарухіна, М. І. Хавронюка, С. В. Шевченка та інших, однак багато питань залишаються невирішеними та потребують подалышого вивчення. Проблеми суб'єктивної сторони злочинів, спрямованих на порушення спеціальних правил безпеки, зокрема безпеки виробництва та безпеки здоров'я населення, вивчали В. І. Борисов, С. В. Гізімчук, О.П.Горох, М.С.Грінберг, М. І. Даньшин, Г. С. Крайник, Б. А. Куринов, І. П. Лановенко, О. П. Литвин, В. К. Матвійчук, П. С. Матишевський, А. А. Музика, О. О. Пащенко, В. П. Самокиш, В. М. Смітієнко, О. А. Смик, В. Я. Тащій, В. П. Тихий, С. В. Фесенко, М. І. Хавронюк та багато інших. Однак питання про зміст вини у таких злочинах зі складною об'єктивною стороною залишається дискусійним, єдиний підхід 3 цього приводу не вироблений.

Формулювання цілей. Тож метою статті є всебічне дослідження змісту вини як обов' язкової ознаки суб' єктивної сторони складу кримінальних правопорушень зі складною об' єктивною стороною, яка передбачає діяння у формі порушення спеціальних правил безпеки та декілька альтернативних наслідків.

Виклад основного матеріалу. Змістовна сторона злочинної поведінки, детермінованої свідомістю і волею індивідууму, виражається в тій чи іншій формі вини, мотивах і меті вчиненого. Проте основу суб' єктивної сторони як психічної діяльності суб'єкта складає його психічне ставлення до вчинюваного суспільно небезпечного діяння і його наслідків у формі умислу чи необережності. Цією основою є вина.

У теорії кримінального права поширеною є думка, що порушення будь-яких правил безпеки характеризується умислом щодо самого порушення (дії чи бездіяльності) і необережністю до настання шкідливих наслідків [1, с. 206; 2, с. 55]. Таке неоднакове суб'єктивне ставлення винної особи до діяння та його наслідків отримало назву «складної форми вини», яку іноді називають також змішаною або подвійною формою вини [2, с. 118; 3, с. 262-282].

На даному етапі розвитку науки кримінального права питання складної вини, як правило, розглядаються у контексті дослідження суб' єктивної сторони складів окремих злочинів. Зокрема, 3. Г. Корчева зазначає, що злочини, пов'язані з порушенням спеціальних правил (безпеки руху, проведення будівельних робіт то- 
що), в усіх випадках учиняються зі складною формою вини, що стає ще очевиднішим в умовах науково-технічного прогресу [4, с. 203]. Є. В. Фесенко, як і більшість дослідників, визнає складну форму вини при вчиненні злочину, передбаченого ст. 326 КК України: він стверджує, що суб'єктивна сторона такого порушення правил характеризується виною у формі умислу щодо вчиненого діяння (особа має усвідомлювати, що порушує правила поводження саме з мікробіологічними чи іншими біологічними агентами або токсинами), необережністю - стосовно реальних наслідків діяння, а щодо факту створення загрози для здоров'я людей чи настання інших тяжких наслідків не виключається і непрямий умисел [5, с. 264]. Зважаючи, що науковець не уточнює, які види умислу щодо порушення відппвідних правил та необережності щодо наслідків характерні для суб'єктивної сторони складу злочину, передбаченого ст. 326 КК України, вважатимемо, що він мав на увазі всі -прямий і непрямий, самовпевненість і недбалість.

Позищія Ю. В. Бауліна у цьому питанні дещо відрізняється. Дослідник упевнений, що із суб'єктивної сторони порушення зазначених правил може бути як умисним, так і необережним, а щодо наслідків - тільки необережним [6, с. 429]. Тобто, не конкретизуючи види умислу і необережності, Ю. В. Баулін, на відміну від $€$. В. Фесенка, вбачає можливість альтернативної форми вини щодо діяння та, не розрізняючи делікт створення небезпеки і матеріальний склад вказаного злочину, безапеляційно вказує лише на необережну (очевидно, обох видів) форму вини щодо наслідків.

Указану позицію поділяє й О. П. Литвин, який зазначає: «Щодо факту порушення правил вина особи може виявлятися у формі умислу або необережності. Що ж до настання або можливості настання тяжких наслідків, то вина може бути тільки необережною. За наявності умислу щодо наслідків скоєне потрібно кваліфікувати за статтями про злочини проти особи або власності» [7, с. 135].

Дещо інше бачення на досліджуване питання в М. І. Хавронюка. Частково поділяючи позицію Ю. В. Бауліна й О. П. Литвина, він вважає, що суб'єктивна сторона цих злочинів характеризується умислом або необережністю до діяння. Водночас, подібно до Є. В. Фесенка, учений розрізняє психічне ставлення винної особи до наслідків у вигляді шкоди здоров' ю потерпілого (необережність) та створення загрози загибелі людей чи настання інших тяжких наслідків (умисел або необережність) [8, с. 1022]. Водночас вбачається некоректним в останньому випадку вказувати в узагальненому виді умисну форму вини. Підхід С. В. Фесенка, який говорить лише про евентуальний умисел, вважаємо більш виваженим.

Як бачимо, більш-менш усталеного підходу до характеристики вини особи при вчиненні злочинів, передбачених ст.ст. 272-275, 326 КК України, серед науковців немає. Зазначене змушує нас детально зупинитися на визначенні особливостей інтелектуальних і вольових моментів умисної та необережної форм вини суб'єкта досліджуваних кримінальних правопорушень.

Усвідомлення особою суспільно небезпечного характеру вчинюваного нею діяння є першою ознакою інтелектуального моменту умислу (як прямого, так і непрямого). Усвідомлення включає, зокрема, не тільки розуміння суб'єктом фактичної сторони того, що вчиняється, але й всіх обставин, що характеризують об' єктивні 
ознаки складу злочину, у тому числі значущість об'єкта і предмета посягання, характеру діяння, місця, часу, способу його вчинення та інших обставин. Крім того, автор поділяє позицію тих науковців, які вважають, що умисел передбачає також усвідомлення тих особливих властивостей (якостей) спеціального суб'єкта, які є конститутивними ознаками конкретного складу злочину [9, с. 84]. Усвідомлення ознак спеціального суб'єкта входить до змісту умислу, тому що вони, визначаючи правове становище суб'єкта, нерозривно пов'язані з його спеціальними обов'язками. Усвідомлення цих обов' язків і того, що вони порушуються діянням, не можливе без усвідомлення ознак, що визначають правове становище особи.

О. О. Пащенко при дослідженні злочинів, пов'язаних із порушенням правил безпеки, зазначає, що під час умисного порушення правил суб'єкт усвідомлює, що його діяння завдає шкоди відносинам безпеки у відповідній сфері і що воно суперечить інтересам осіб, які знаходяться у цій сфері. Для усвідомлення особою суспільно небезпечного характеру діяння необхідне відображення (хоча б у загальних рисах) об' єкта злочину, якому спричиняється шкода. 3 приводу порушення правил безпеки, суб'єкт усвідомлює, що саме внаслідок його діяння (порушення) знижується рівень безпеки у відповідній сфері й через це можуть настати суспільно небезпечні наслідки у вигляді загибелі людей, забруднення довкілля, спричинення матеріальної шкоди тощо. Крім того, до змісту усвідомлення входить (хоча б у загальних рисах) передбачення розвитку причинного зв'язку [10, с. 75].

3 огляду на викладене, інтелектуальний момент умисного порушення спеціальних правил безпеки передбачає усвідомлення суб'єктом того, що: 1) механізми, виробничі процеси, речовини, матеріали, агенти, які він використовує у свойй виробничій, досліднищькій, медичній та іншій діяльності, є небезпечними; 2) на ньому лежить обов' язок дотримання відповідних правил, з якими він обізнаний; 3) він порушує ці правила та свій обов' язок; 4) його дії (бездіяльність) знижують рівень безпеки у відповідній сфері.

Усвідомлення винним суспільно небезпечного характеру вчинюваного ним діяння зумовлене передбаченням настання суспільно небезпечних наслідків цього діяння. Передбачення, друга ознака інтелектуального моменту умислу, означає, що у свідомості даної особи склалося певне уявлення про можливі (ймовірні) чи неминучі наслідки свого діяння.

Зважаючи на те, що суспільно небезпечні наслідки досліджуваних основних складів злочинів різняться за своєю природою (одні - це створення реальної загрози, інші - заподіяння шкоди здоров'ю людини), відповідним чином і психічне ставлення особи до них є неоднозначним.

Наприклад, свідомо порушуючи правила поводження з біологічними патогенними агентами (ст. 326 КК України), особа передбачає лише можливість (а не неминучість) виходу таких патогенів 3-під контролю, тобто вірогідність створення біологічної загрози. За такої умови суб'єкт у цілому розуміє закономірність такого розвитку подій, тобто передбачає причинний зв' язок між порушенням ним відповідних правил та створенням в результаті цього ситуації біологічної небезпеки. Отже, ідеться про непрямий умисел. 
Чи може при умисному порушенні спеціальних правил безпеки суб'єкт передбачати реальну можливість альтернативного розвитку подій - заподіяння шкоди здоров'ю іншої особи? На наше переконання, ні, інакше таке діяння особи виходитиме за межі складів злочинів, передбачених ст.ст. 272-275, 326 КК України. У такому разі йтиметься, перш за все, про кримінальні правопорушення проти життя та здоров' я особи, передбачені розділом II Особливої частини КК України (наприклад, ч.1 ст. 121, ч.1 ст. 122, ч.1 ст. 130, ч.1 ст. 131) або деякі інші.

Аби переконатися в доречності наших висновків, розглянемо зміст вольового моменту умислу, який означає наявність у суб'єкта злочину бажання настання суспільно небезпечних наслідків як результату вчиненого ним діяння чи свідомого їх допущення.

При прямому умислі вольовий момент, який характеризується цілеспрямованим регулюванням поведінки, прагненням досягти злочинного результату, задовольнити ту чи іншу потребу, визначається в законі як бажання настання суспільно небезпечних наслідків. Тобто винний ставиться до злочинного результату як до потрібної йому події. При непрямому умислі винний не прагне заподіяти суспільно небезпечні наслідки, вони не потрібні йому, він не бажає, проте свідомо допускає ïx настання. За такої умови злочинний наслідок не є ані метою дій винного, ані засобом іï досягнення, ні етапом на шляху до мети. Тут воля винного посідає, на відміну від прямого умислу, не активну, а пасивну позицію щодо шкідливих наслідків. Тобто при непрямому умислі вольовий момент виражається в байдужному ставленні особи до наслідків свого діяння.

Тож особа, свідомо порушуючи спеціальні правила безпеки, не бажає, але свідомо допускає можливість руйнування або пошкодження знарядь праці, будівель, детонації вибухонебезпечних об'єктів, вивільнення радіоактивних матеріалів, біологічних агентів чи інших небезпечних речовин в оточуюче середовище тощо. Тобто суб' єкт не зацікавлений у настанні цих наслідків, хоча й передбачає їх, не має потреби в створенні загрози вибуху, аварії, опромінення, зараження інших осіб або забруднення довкілля, однак внутрішньо з цим погоджується. Таке пасивне небажання рівноцінне байдужості до зазначених шкідливих наслідків суспільно небезпечної поведінки [11, с. 188]. Отже, створення загрози загибелі людей чи настання інших тяжких наслідків у цьому випадку не визначається мотивами поведінки винного.

Особливістю ситуації небезпеки є те, що вона, по-перше, не має самостійної цінності для суб'єкта i, по-друге, здатна викликати заподіяння шкоди самому порушникові правил безпеки. Тому, мабуть, неможливо стверджувати, що, порушуючи правила та норми, спрямовані на дотримання режиму виробничої, технологічної, хімічної або біологічної безпеки, винна особа прагне створити небезпечну ситуацію, бажає тим самим поставити під загрозу своє життя і здоров'я, як і життя інших осіб. Такі дії (бездіяльність) можуть бути зумовлені різними причинами, але не бажанням створити небезпеку. Тому вольове ставлення особи до факту створення його діянням ситуащії небезпеки може виявлятися не у вигляді бажання (праг- 
нення), а лише у вигляді свідомого допущення цього суспільно небезпечного результату, що характерно для непрямого умислу, або легковажного розрахунку на недопущення таких загроз (злочинна самовпевненість).

Таким чином, прямий умисел до настання суспільно небезпечних наслідків першого порядку (делікт створення небезпеки) при порушенні спеціальних правил безпеки виключається. Натомість може мати місце непрямий умисел: суб' єкт, свідомо порушуючи встановлені спеціальні правила безпеки, передбачає реальну можливість втрати контролю над механізмами, виробничими процесами, речовинами, матеріалами, агентами та можливість вибуху, аварії, опромінення, зараження інших осіб або забруднення довкілля і хоча не бажає, але свідомо допускає настання таких наслідків (ставиться з байдужністю до можливості їх настання).

До наслідків другого (заподіяння шкоди здоров'ю потерпілого), а тим більше третього порядку (спричинення загибелі людей чи інших тяжких наслідків - кваліфікований склад злочину) при порушенні спеціальних правил безпеки можливим $є$ лише необережне ставлення.

Необережність поряд з умислом є самостійною формою вини у кримінальному праві. Необережні злочини - результат легковажного ставлення до суспільних інтересів чи недостатньо серйозної уваги до своїх дій та їх можливих наслідків. Необережністю законодавець вважає два відносно самостійні види прояву психічного ставлення особи до суспільно небезпечних наслідків своїх дій: злочинну самовпевненість і злочинну недбалість (ст. 25 КК України). Ці види необережності також можуть бути охарактеризовані за допомогою вольового та інтелектуального моментів.

Інтелектуальнии момент злочинної самовпевненості проявляється у такому вигляді: розуміючи фактичну сторону своїх дій або бездіяльності, суб'єкт передбачає абстрактну можливість настання шкідливих наслідків, однак упевнений, що вони не настануть завдяки обраному ним варіанту поведінки.

Так, свідомо порушуючи правила ядерної або радіаційної безпеки, суб' єкт передбачає, що діяння, подібні до вчиненого ним, взагалі-то можуть заподіяти шкоду здоров'ю інших осіб, однак упевнений, що вчинена саме ним дія (бездіяльність) не призведе до виходу відповідних радіоактивних матеріалів 3-під контролю. Тому, діючи (не діючи) у відповідній конкретній обстановці, особа не усвідомлює і реального розвитку причинного зв' язку між своєю поведінкою і наслідками, хоча й могла це зробити за більшого напруження своїх інтелектуальних можливостей.

Своєрідність больового ставлення винного до наслідків свого діяння при злочинній самовпевненості полягає в наявності розрахунку відвернути наслідки. При тому особа розраховує на досить конкретні, реально існуючі обставини, які, за ії переконанням, здатні не допустити, об' єктивно протидіяти настанню злочинного результату. Такими обставинами можуть бути, зокрема, особисті якості винного (досвід, майстерність тощо), дії інших осіб, сил природи або механізмів, а також інші певні обставини, значення яких особа неправильно оцінює, унаслідок чого їі розрахунок виявляється безпідставним, легковажним і злочинного результату уникнути не вдається. 
Як слушно вказує $Є$. В. Фесенко, такий розрахунок може полягати в тому, що особа легковажно орієнтується на аналогічні випадки, коли таке порушення нею або іншими особами зазначених правил не призводило до тяжкого наслідку, або намагається запобігти наслідкові безпосередньо своїми діями (застосовує препарати, робить дезінфекцію тощо). Але суб'єкт діяння помиляється, оскільки наслідки все ж таки настають. Урешті-решт особа не враховує дійсного розвитку події, саме того причинно-наслідккового зв' язку, який призводить до шкідливого наслідку для здоров'я населення [5, с. 193].

3 огляду на це, злочинна самовпевненість щодо суспільно небезпечних наслідків при порушенні спеціальних правил безпеки буде мати місце, якщо особа, нехтуючи цими правилами, легковажно розраховувала, що не допустить виходу небезпечних механізмів, процесів, речовин, матеріалів, агентів 3-під контролю, однак вжиті нею запобіжні заходи виявилися недостатніми. Тобто суб'єкт не тільки не бажає, але й не допускає настання наслідків у вигляді вибухів, аварій, опромінення, зараження інших осіб, забруднення довкілля, руйнування або пошкодження знарядь праці, будівель. Ба більше, особа спрямовує свою поведінку на відвернення зазначеного негативного результату й упевнена в успіху. Однак упевненість ця виявляється помилковою, і наслідки, що суперечать вольовій спрямованості суб'єкта, настають [11, с. 198-199]. За таких обставин ідеться про поверхневий, легковажний характер процесу мислення та свідомості, через що сама надія (впевненість) на уникнення нещасних випадків, є неспроможною.

Інтелектуальний зміст злочинної недбалості характеризується двома ознаками: негативними та позитивними. Негативна ознака злочинної недбалості - непередбачення особою можливості настання суспільно небезпечних наслідків - містить у собі як відсутність усвідомлення суспільно небезпечного характеру вчинюваного діяння, так і відсутність передбачення шкідливих наслідків. Винний не передбачає або можливості фактичного настання цих наслідків, або не передбачає їх суспільно небезпечного характеру [12, с. 93].

Зважаючи на викладене, автор поділяє позищію Г. С. Крайника [13] і стверджує, що при умисному порушенні спеціальних правил безпеки необережне ставлення до суспільно небезпечних наслідків як першого, так і другого порядку у вигляді злочинної недбалості є неможливим, адже при злочинній недбалості суб'єкт не розуміє небезпечність ситуації і не передбачає, що в результаті його дій чи бездіяльності відбудеться вибух, аварія, пошкодження агрегатів, механізмів, руйнування будівель, вивільнення небезпечних для людини чи довкілля радіоактивних, токсичних речовин чи патогенів (звичайно, за умови, що він повинен був і міг це передбачити).

Інакше кажучи, у разі недбалого ставлення до суспільно небезпечних наслідків, передбачених диспозищіями ст.ст. 272-275, 326 КК України, суб' ективна сторона досліджуваних складів злочинів характеризується не складною формою вини, а необережністю у виді злочинної недбалості (як щодо порушення відповідних правил, так і суспільно небезпечних наслідків).

Непередбачення можливості втрати контролю над небезпечними механізмами, виробничими процесами, речовинами, матеріалами, агентами, що потягло 
за собою вибух, аварію, опромінення, зараження інших осіб або забруднення довкілля тощо, зазвичай має місце в результаті недогляду, забутливості, неуважності, необачності, зневажливого ставлення до своїх обов' язків. В усіх цих випадках суб'єкт не усвідомлює суспільної небезпечності вчинюваного ним діяння, у нього відсутнє передбачення можливості настання суспільно небезпечних наслідків від цього діяння.

Позитивна ознака інтелектуального моменту недбалості полягає в тому, що особа повинна була (об'єктивний критерій) і могла (суб'єктивний критерій) передбачити настання фактично заподіяних суспільно небезпечних наслідків [1, с. 201-202].

Об'єктивний критерій злочинної недбалості грунтується на вимогах персональної відповідальності суб'єкта й означає обов' язок конкретної особи передбачати можливість настання суспільно небезпечних наслідків при здійсненні нею дій, що вимагають особливої уважності, обачності. При визначенні об' єктивного критерію недбалого порушення спеціальних правил безпеки необхідно виходити з того, що обов' язок бути уважним і обачним при поводженні з небезпечними механізмами, виробничими процесами, речовинами, матеріалами, штамами пов' язаний зі спеціальною освітою, кваліфікацією та чіткими посадовими інструкціями всіх осіб, допущених до відповідних робіт. Такий обов' язок випливає також із спеціальних законів, норм, правил, вимог, державних стандартів та інших нормативів, які регулюють діяльність, пов' язану з підвищеною небезпекою.

Таким чином, за наявності об'єктивного обов' язку передбачити наслідки, необхідно встановити, що особа реально мала можливість у даному конкретному випадку передбачити їх настання, але ця можливість суб'єктом не була реалізована і наслідків уникнути не вдалося.

Суб'єктивний критерій виражає фактичну можливість особи передбачати суспільно небезпечні наслідки своїх діянь. Ця можливість залежить від індивідуальних якостей особи (соціальні та психофізіологічні особливості людини, зумовлені їі соціальним досвідом, способом життя, професійними, інтелектуальними і вольовими якостями, а також її стан у момент вчинення злочину) та від тієї конкретної обстановки, у якій діяла дана особа (повнота зовнішніх об'єктивних даних, адекватність відображення зовнішніх обставин у свідомості особи). Без урахування та оцінки суб'єктивного критерію не можна говорити про наявність у суб' єкта можливості передбачати суспільно небезпечні наслідки свого вчинку.

Вольовий момент злочинної недбалості полягає в тому, що винний, маючи реальну можливість передбачити суспільно небезпечні наслідки вчинюваного ним діяння, не активізує свої психічні сили та здібності для здійснення вольових дій, необхідних для відвернення суспільно небезпечних наслідків, i, отже, не перетворює реальну можливість на дійсність. Таким чином, вольовий момент недбалого порушення спеціальних правил безпеки полягає в недостатньому напруженні психічних сил, немобілізації своїх здібностей з метою перетворення на дійсність реально наявної можливості передбачити те, що контроль над небезпечними механізмами, виробничими процесами, речовинами, матеріалами, агентами може бути втрачений. Інакше кажучи, у такій ситуації має місце вада волі: непередбачення наслідків 
настає в результаті недостатнього психічного регулювання поведінки, вибору помилкового рішення.

3 урахуванням викладеного, злочинна недбалість при вчиненні злочинів, передбачених ст.ст. 272-275, 326 КК, має місце, якщо винний не усвідомлює, що механізми, виробничі процеси, речовини, матеріали, агенти, які він використовує у свойй виробничій, досліднищькій, медичній та іншій діяльності, є небезпечними, або що він порушує певні правила безпеки, або що його дії створюють умови втрати контролю над небезпечними механізмами, виробничими процесами, речовинами, матеріалами, агентами, хоча в умовах, що склалися, повинен був і міг це усвідомлювати та передбачати можливість руйнування або пошкодження знарядь праці, будівель, детонації вибухонебезпечних об'єктів, вивільнення радіоактивних матеріалів, біологічних агентів чи інших небезпечних речовин в оточуюче середовище, але не активізує свою волю в напрямку такого передбачення та відвернення цих наслідків.

Як факти злочинної недбалості слід розцінювати, наприклад, такі діяння, коли: особа після закінчення робіт з біологічними патогенними агентами забуває обробити руки $70^{\circ}$ етиловим спиртом або ввімкнути бактерицидні лампи, а потім відбувається інфікування іншого персоналу, який контактував із відповідними контамінованими поверхнями (дверні ручки, меблі, стіни, холодильники тощо); особа забуває знезаразити заражені патогенними мікроорганізмами матеріали, зразки або культури перед їх видаленням з лабораторії, унаслідок чого відбувається вивільнення патогенів у зовнішнє середовище; особа по недогляду ставить в один холодильник живі культури патогенних мікроорганізмів і лікувальні препарати, що призводить до інфільтрації патогенів до таких препаратів та подальшого інфікування персоналу або пацієнтів. В усіх цих випадках особа не усвідомлювала, що вона порушує правила поводження з біологічними патогенними агентами, хоча при більш уважному ставленні до своїх обов'язків повинна була і могла передбачити можливість вивільнення патогенів у зовнішнє середовище.

Висновки. Проведене дослідження дозволяє констатувати, що при умисному порушенні спеціальних правил безпеки психічне ставлення особи до суспільно небезпечних наслідків першого порядку (створення реальної загрози загибелі людей чи настання інших тяжких наслідків) характеризується непрямим умислом або злочинною самовпевненістю. В останньому випадку йдеться про складну форму вини. Прямий умисел до настання суспільно небезпечних наслідків першого порядку при порушенні спеціальних правил безпеки виключається. До наслідків другого (заподіяння шкоди здоров'ю потерпілого) та третього порядку (спричинення загибелі людей чи інших тяжких наслідків - кваліфікований склад злочину) при порушенні спеціальних правил безпеки можливим є лише необережне ставлення винуватої особи. Водночас при умисному порушенні спеціальних правил безпеки необережне ставлення до суспільно небезпечних наслідків (як безпосередніх, так і відділених) у вигляді злочинної недбалості є неможливим. Тобто в разі недбалого ставлення до суспільно небезпечних наслідків, передбачених диспозиціями ст.ст. 272-275, 326 КК України, суб'єктивна сторона цих правопорушень характеризується не складною формою вини, а необережністю у виді злочинної недбалості (як 
відносно порушення відповідних правил, так і відносно суспільно небезпечних наслідків).

Перспективним напрямком подальших досліджень автор вважає розробку правової норми про визначення змісту складної (подвійної) форми вини у кримінальних правопорушеннях зі складною об'єктивною стороною з метою вдосконалення чинного законодавства України про кримінальну відповідальність.

\section{Використані джерела:}

1. Дудоров О. О., Хавронюк М. І. Кримінальне право : навч. посібник / За заг. ред. М. І. Хавронюка. Київ : Ваіте, 2014. 944 с.

2. Ємельянов В. П. Кримінальне право України : Загальна частина. Основні питання вчення про злочин: наук.-практ. посіб. Харків : Право, 2018. 142 с.

3. Вереша Р. В. Проблеми суб'єктивної сторони складу злочину: дис. ... доктора юр. наук : спец. 12.00.08. Київ : Академія адвокатури України; Національна академія внутрішніх справ, 2017. 583 с.

4. Корчева 3. Г. Сложная форма вины в преступлениях, связанных с нарушением специальных правил. Проблемы соииалистической законности на современном этапе коммунистического строительства: тез. докл. и науч. сообщ. респ. науч. конф. (Харьков, 21-23 ноября 1978 г.). Харьков : Юрвуз, 1978. С. 203-204.

5. Фесенко Є. В. Злочини проти здоров'я населення та системи заходів 3 його охорони: дис. ... доктора юр. наук : спец. 12.00.08. Київ : Академія адвокатури України, 2004. 426 с.

6. Кримінальне право України : Особлива частина : підручник / Ю. В. Баулін, В. I. Борисов, В. І. Тютюгін та ін.; за ред. проф. В. Я. Тація, В. І. Борисова, В. І. Тютюгіна. 5-те вид., переробл. і допов. Харків : Право, 2015. 680 с.

7. Литвин О. П., Ящуринський Ю. В. Правоохоронна діяльність у сфері забезпечення загальної громадської безпеки : навч. посіб. Київ : МАУП, 2006. 239 с.

8. Науково-практичний коментар Кримінального кодексу України / за ред. М. І. Мельника, М. І. Хавронюка. 11-те вид., переробл. та допов. Київ : ВД «Дакор», 2019. 1384 с.

9. Дагель П. С., Котов Д. П. Субъективная сторона преступления и её установление. Воронеж : Изд-во Воронежского гос. ун-та, 1974. 243 с.

10. Пащенко О. О. Особливості психічного ставлення суб'єкта до суспільно небезпечного діяння у злочинах, пов'язаних з порушенням правил безпеки. Вісник прокуратури. 2007. № 6 (72). С. 71-76.

11. Ойгензихт В. А. Воля и волеизъявление: Очерки теории, философии и психологии права / Отв. ред. С. А. Раджабов. Душанбе : Дониш, 1983. 256 с.

12. Вереша Р. В. Необережність та її види (коментар до ст. 25 КК України). Вісник Академії адвокатури України. 2011. № 2 (21). С. 91-94.

13. Крайник Г. С. Вина як ознака суб'єктивної сторони порушення правил безпеки під час виконання робіт з підвищеною небезпекою. Теорія і практика правознавства. 2013. Вип. 2. URL : http://nbuv.go.ua/UJRN/tipp_2013_2_51.

\section{References:}

1. Dudorov, O. O., Khavroniuk, M. I. (2014) Kryminalne pravo : navch. posibnyk / Za zah. red. M. I. Khavroniuka. Kyiv : Vaite. [in Ukrainian].

2. Yemelianov, V. P. (2018) Kryminalne pravo Ukrainy : Zahalna chastyna. Osnovni pytannia vchennia pro zlochyn: nauk.-prakt. posib. Kharkiv : Pravo. [in Ukrainian]. 
3. Veresha, R. V. (2017) Problemy sub'iektyvnoi storony skladu zlochynu : Doktor's thesis. Kyiv : Akademiia advokatury Ukrainy; Natsionalna akademiia vnutrishnikh sprav. [in Ukrainian].

4. Korcheva, Z. H. (1978) Slozhnaia forma viny v prestuplenijakh, sviazannykh s naru sheniem spetsialnykh pravil. Problemy sotsialisticheskoi zakonnosti na sovremennom etape kommunisticheskogo stroitelstva: tez. dokl. i nauch. soobshch. resp. nauch. konf. (Kharkov, 21-23 noiabria 1978 g.). Problems of socialist legality at the present stage of communist construction: abstracts. Report and scientific message resp. scientific conf. (Kharkov, November 21-23, 1978). Kharkov : Yurvuz, 203-204. [in Russian].

5. Fesenko, Ye. V. (2004) Zlochyny proty zdorov' ia naselennia ta systemy zakhodiv z yoho okhorony: Doktor's thesis. Kyiv : Akademiia advokatury Ukrainy. [in Ukrainian].

6. Kryminalne pravo Ukrainy : Osoblyva chastyna : pidruchnyk (2015) / Yu. V. Baulin, V. I. Borysov, V. I. Tiutiuhin (Eds.) et al.; V. Ya. Tatsii, \& V. I. Borysov, \& V. I. Tiutiuhin (Eds.). 5-te vyd., pererobl. i dopov. Kharkiv: Pravo. [in Ukrainian].

7. Lytvyn, O. P., Yashchurynskyi, Yu. V. (2006) Pravookhoronna diialnist u sferi zabezpechennia zahalnoi hromadskoi bezpeky : navch. posib. Kyiv : MAUP. [in Ukrainian].

8. Naukovo-praktychnyi komentar Kryminalnoho kodeksu Ukrainy (2019) / M. I. Melnyk, M. I. Khavroniuk (Ed.). 11-te vyd., pererobl. ta dopov. Kyiv : VD «Dakor». [in Ukrainian].

9. Dahel, P. S., Kotov, D. P. (1974) Subektivnaia storona prestupleniia i eio ustanovlenie. Voronezh : Izd-vo Voronezhskoho gos. un-ta. [in Russian].

10. Pashchenko, O. O. (2007) Osoblyvosti psykhichnoho stavlennia sub'iekta do suspilno nebezpechnoho diiannia u zlochynakh, pov'iazanykh z porushenniam pravyl bezpeky. Visnyk prokuratury - Bulletin of the prosecutor's office, 6 (72), 71-76. [in Ukrainian].

11. Oigenzikht, V. A. (1983) Volia i voleizjavlenie: Ocherki teorii, filosofii i psikhologii prava / S. A. Radzhabov (Ed.). Dushanbe : Donish. [in Russian].

12. Veresha, R. V. (2011) Neoberezhnist ta yii vydy (komentar do st. 25 KK Ukrainy). Visnyk Akademii advokatury Ukrainy - Bulletin of the Academy of Advocacy of Ukraine, 2(21), 91-94. [in Ukrainian].

13. Krainyk, H. S. (2013) Vyna yak oznaka sub'iektyvnoi storony porushennia pravyl bezpeky pid chas vykonannia robit z pidvyshchenoiu nebezpekoiu. Teoriia i praktyka pravoznavstva. - Theory and practice of jurisprudence, issue 2. URL : http://nbuv.go.ua/UJRN/tipp_2013_2_51. [in Ukrainian].

Стаття надіӥшла до редколегї̈ 08.08.2021

Шамсутдинов А. В., кандидат юридических наук, профессор кафедры уголовного права, уголовного процесса и криминалистики Национальной академии Службы безопасности Укра ины (2. Киев, Украина)

\section{ОСОБЕННОСТИ СОДЕРЖАНИЯ ВИНЫ В УГОЛОВНЫХ ПРАВОНАРУШЕНИЯХ СО СЛОЖНОЙ ОБЪЕКТИВНОЙ СТОРОНОЙ (СТАТЬИ 272-275, 326 УК УКРАИНЫ)}

В статье проведено исследование по вопросу содержания вины как обязательного признака субъективной стороны состава уголовных правонарушений со сложной объективной стороной, которая предусматривает деяние в форме нарушения специальных правил безопасности и несколько альтернативных последствий. Детально рассмотрены особенности интеллектуальных и волевых моментов умышленной и неосторожной форм вины в уголовных правонарушениях, предусмотренных статьями 272-275, 326 УК 
Украины. Сделан вывод о том, что при умьшшенном нарушении специальных правил безопасности психическое отношение лица к общественно опасным последствиям первого порядка (создание реальной угрозы) характеризуется косвенным умыслом или преступной самонадеянностью, а к последствиям второго и третьего порядка (причинение реального вреда) возможно лишь неосторожное отношение виновного лица. Аргументировано утверждение, что с преступной небрежностью при совершении исследуемых преступлений субъект относится как к деянию, так и к его последствиям, то есть сложная форма вины исключается.

Ключевые слова: вина, сложная форма вины, умысел, неосторожность, нарушение специальных правил безопасности, деликт создания опасности.

Shamsutdinov O., Ph.D. in Law, Professor at the Department of Criminal Law, Criminal Procedure and Criminalistics, National Academy of Security Service of Ukraine (Kyiv, Ukraine)

\section{CONTENT FEATURES OF GUILT IN CRIMINAL OFFENSES WITH A COMPLEX ACTUS REUS (ARTICLES 272-275, 326 OF THE CRIMINAL CODE OF UKRAINE)}

The article examines the content of guilt as an obligatory feature of the mens rea (subjective side) of the criminal offenses with complex actus reus (objective side), which provides for activities in the form of a violation of special safety rules and several alternative consequences (Articles 272-275, 326 of the Criminal Code of Ukraine).

The author makes a hypothesis that the complex structure of the actus reus (objective side) of these criminal offenses, particularly the mandatory alternative consequences of different levels (immediate and following) causes a complex mental attitude of the perpetrator to his criminal activities and outcomes, considering complex form of guilt. To prove the thesis, the author cites the positions of scientists engaged in scientific research in this area, and argues own point of view.

The peculiarities of intellectual and volitional moments of intentional and negligent forms of guilt on criminal offenses under Articles 272-275, 326 of the Criminal Code of Ukraine are considered in detail. It is concluded that in case of intentional violation of special safety rules, a person's mental attitude to socially dangerous consequences of the first level (creating a real threat of death or other severe consequences) is characterized by eventual intent or criminal arrogance. In the latter case, it is a complex form of guilt. It is stated that direct intent to socially dangerous consequences of the first level (creating a real threat of death or other severe consequences) in violation of special safety rules (this is about delict of the creating of danger) is excluded.

It is argued that the perpetrator's attitude to the consequences of the second (causing harm to the health of the victim) and the third levels (causing death or other serious effects - a qualified corpus delicti) can be only negligent. It the conclusion it is stated that in case of negligent attitude to socially dangerous consequences of the considered criminal offenses mens rea (subjective side) of these crimes is characterized not by a complex form of guilt, but by negligence in the form of carelessness (both concerning violation of the rules and socially dangerous consequences).

Keywords: guilt, complex form of guilt, intent, negligence, violation of special safety rules, delict of the creating of danger. 